\title{
Data integration from intensive observation period in 2016 to detect extreme weather in the vicinity of Jakarta region
}

\author{
Nyayu Fatimah Zahroh ${ }^{1,}$, Budi Darmawan Supatmanto ${ }^{1}$, Sholehhudin Al Ayubi ${ }^{1}$, Mahally Kudsy ${ }^{1}$, Edvin Aldrian ${ }^{1}$, \\ Findy Renggono ${ }^{1}$, Jon Arifian ${ }^{1}$, Rino Bachtiar Yahya ${ }^{1}$, and Satyo Nuryanto ${ }^{1}$ \\ ${ }^{1}$ National Laboratory for Weather Modification Technology, BPPT, Serpong, South Tangerang, 15314, Indonesia
}

\begin{abstract}
Meteorological hazard has been frequently occurred in Indonesia due to torrential rains. It is important to examine the characteristics of the atmosphere during rainy seasons for hazard mitigation. National Laboratory of Weather Modification Technology has conducted a short Intensive Observation Program (IOP) from January 18th to February 16th, 2016 to collect meteorological data in the vicinity of Jakarta Region. During that period several instruments have been used, such as Radar, Microwave Profiling Radiometer, Automatic Weather Station, and Radiosonde. This paper examines the comparison of atmospheric parameters obtained from Radiosonde and Profiling Radiometer during extreme weather days. The results showed that there were significant differences of instability indices of Radiosonde and Profiling Radiometer data: 15 points for KI, 6 points for TT and 100 points for SWEAT. The atmospheric stability indices of the Profiling Radiometer tended to be lower than Radiosonde. A radar image showing a rainstorm as well as rain rate information validates atmospheric index stability data. Radar and atmospheric instability indices data integration can be used as one of the parameters to forecast extreme weather events and as an early warning system of hazard mitigation.
\end{abstract}

\section{Introduction}

Meteorological hazard has been frequently occurred in Indonesia due to torrential rains. It is important to understand the characteristics of the atmosphere during rainy seasons for hazard mitigation. National Laboratory of Weather Modification Technology (commonly called BB-TMC) at Agency for Assessment and Application of Technology (BPPT) has conducted a short Intensive Observation Program (IOP) during January 18th to February 16th, 2016, to collect meteorological data in the vicinity of Jakarta Region. During that period several instruments namely weather radar, Microwave Profiling Radiometer, Automatic Weather Station (AWS), and Radiosonde have been used to collect critical meteorological data. This paper will discuss the comparison of atmospheric parameters obtained from Radiosonde, Profiling Radiometer, and Radar during extreme weather days.

Many research on Radiosonde and Profiling Radiometer has been done, such as by Athoillah [1] that compared the air temperature and relative humidity from each instrument. Besides, Renggono [2] and Zahroh [3] had been used data from both tools to observe the precipitation cloud growth and to predict thunderstorms. Further Renggono [2] also conducted research using Radar data on IOP for cloud movement and development.

The Radiosonde data can be used for forecasting convection that can produce rain with thunderstorms [4-7]. It is essential to predict the occurrence of extreme weather as early as possible to provide security when dangerous weather threatens. Besides, extreme weather early warning information can help protect life and property.

In this research, we want to refine the previous study by comparing the instability indices produced by Radiosonde and Profiling Radiometer. The sounding data was then verified with radar to define the instability indices of the Radiosonde and Profiling Radiometer. These indices can improve the prediction of the extreme weather.

\section{The Material and method}

The data used for this research is from Radiosonde, Profiling Radiometer, Automatic Weather Station, and Radar from IOP activity on January 28th - 31st, 2016. All the observation was carried out at BMKG (Meteorology Climatology and Geophysics Agency) Weather Station, Dramaga, Bogor, except for the radar was conducted at the Centre for Research, Science and Technology (Puspiptek), South of Tangerang. By processing Radiosonde and Profiling Radiometer data using RAOB software, instability indices (TT index, K Index, and SWEAT) can be produced. From the indices data, the character of atmospheric stability on those dates can be obtained.

\footnotetext{
Corresponding author: nyayu.fatimah@bppt.go.id
} 


\subsection{Radiosonde}

Radiosonde was launched four times a day with the frequency every 6 hours at 00.00 UTC, 06.00 UTC, 12.00 UTC and 18.00 UTC. Usually, Radiosonde is launched twice a day. With higher intensity of the launching, we expect to be able to analyse the condition of atmospheric stability better.

\subsection{Microwave profiling radiometer}

A Microwave Profiling Radiometer is a passive receiver that serves to measure air temperature, relative humidity and liquid water content in the air up to 10,000 meters vertically [2]. Based on its function, the Profiling Radiometer has a similar capacity with Radiosonde. But, a Profiling Radiometer is static while the Radiosonde is dynamic. So, there must be a difference between the data generated.

Some researcher studied the comparison between Profiling Radiometer and Radiosonde. It was shown in Athoillah [1] that data from Profiling Radiometer and Radiosonde have a similarity, especially in the event of extreme rain. Besides, it has been proven that the air temperature and relative humidity data generated by Profiling Radiometer had similarities with the data generated from Radiosonde [1].

\subsection{Furuno radar}

The Furuno radar is a dual polarization Doppler XBand placed at a level of about 10 meters from the surface, and it used to discover the particles present in the atmosphere [8]. Solid state radars that work at a frequency of about $9.4 \mathrm{GHz}$ beam width of 2.7 degrees and can observe clouds up to a radius of $50 \mathrm{~km}$. The data was processed into CAPPI data using the furuno2draft program (Taishi Hashimoto from ILOHA Project Corp) and the DRAFt (Development of Radar Analysis software and data format, which developed by Yoshinobu Tanaka from MRI) program.

\subsection{Instability indices}

The instability indices are used to determine the atmospheric stability at the time of the measurements were taken. There are several instability indices in RAOB Software output that used to analyse air stability conditions such as $\mathrm{K}$ index, Lifted Index, CAPE, Total-totals Index, Showalter Index and SWEAT. This study uses $\mathrm{K}$ index (KI), Total-totals (TT), and SWEAT to determine the condition of atmospheric stability in light and moderate rain conditions on January 28-31 and February 1-2, 2016. The indices were selected for widely used to analyse atmospheric stability conditions in tropical regions particularly in Indonesia [7, 9-13].

\section{$2.5 \mathrm{~K}$ Index}

$\mathrm{K}$ Index is a measurement of the potential for hurricanes due to convective motion measured by the hose of vertical temperature and atmospheric humidity. The KI is calculated based on the air temperature in the layers of 850,700 , and $500 \mathrm{mb}$ and the dew point on the layers of 850 and $700 \mathrm{mb}$. Here is the KI equation:

$$
K I=T 850-T 500+T d 850-(T 700-T d 700)
$$

Where:

$\mathrm{T}=$ air temperature

$\mathrm{Td}=$ dew point temperature

The more significant the temperature difference between the layers of 850 and $500 \mathrm{mb}$, the higher the moisture and the higher the value of the KI. The same condition applied when the quantity of KI is higher, the potential convection is also higher.

\subsection{Total-totals index (TT)}

The total-totals index is an index that can determine the convection process which is a combination of vertical totals and cross totals index. Vertical totals represent the difference between the ambient temperature at layers of $850 \mathrm{mb}$ and $500 \mathrm{mb}$, while cross totals represent the difference between the dew point temperature at $850 \mathrm{mb}$ layer with the environmental temperature at $500 \mathrm{mb}$ layer. Below is the total-totals index equation:

$$
T T=(T 850-T 500)+(T d 850-T 500)
$$

Where:

$\mathrm{T}=$ ambient temperature

$\mathrm{Td}=$ the dew point temperature

The higher temperature and humidity in the layer of $850 \mathrm{mb}$ and the lower the temperature at $500 \mathrm{mb}$ layer, then the greater the TT value or unstable atmospheric conditions.

\subsection{SWEAT}

SWEAT (Severe Weather Threat Index) is an index to analyze the potential of severe weather, while at the same time still considering other mechanisms that affect the occurrence of severe weather.

$$
\begin{aligned}
S W E A T= & 12 T d 850+20(T T-49)+2 f 850+f 500+ \\
& 125(s+0.2)
\end{aligned}
$$

Where:

$\mathrm{Td}=$ the dew point temperature,

TT $=$ total-totals index,

$\mathrm{f}=$ wind speed (knots), and wind directions in layer $500 \mathrm{mb}$ and $850 \mathrm{mb}$.

Budiarti [9] had reviewed atmospheric stability indices that are more suitable for low latitude areas. It 
is because the range of the existing index is a study in the subtropical region, and it less ideal for tropical areas. The stability indexes studied were the Totaltotals index, K-Index, and SWEAT. Here are the results of the review.

Table 1. Interval of Atmospheric Stability Indices for Tropical Regions [9].

\begin{tabular}{|c|c|c|c|}
\hline Indices & Weak & Moderate & Strong \\
\hline TT Index & $<42$ & $42-46$ & $>46$ \\
\hline K Index & $<29$ & $29-37$ & $>37$ \\
\hline SWEAT & $<135$ & $135-239$ & $>239$ \\
\hline
\end{tabular}

\section{Results and discussion}

According to BMKG (Meteorology Climatology and Geophysics Agency), rainfall intensity is divided into four categories, i.e. light rain $(5-20 \mathrm{~mm} \mathrm{/} \mathrm{day),}$ moderate rain (5 20-50 mm / day), heavy rain (50-100 $\mathrm{mm} /$ day) and very heavy rain (> $100 \mathrm{~mm} /$ day). Looking at the rainfall data attached to table 1 , the rainfall that occurred on January 28 and 31 can be categorized into a moderate rain. While rain on 29 and 30 January 2016 is light rain.

Table 2. Rainfall Data at BMKG, Dramaga.

\begin{tabular}{|c|c|}
\hline Date & Precipitation (mm) \\
\hline 28-Jan-16 & 48 \\
\hline 29-Jan-16 & 18 \\
\hline 30-Jan-16 & 2.6 \\
\hline
\end{tabular}

Figure 1 to 4 show the comparison of atmospheric stability indices of Radiosonde and Profiling Radiometer data that had been processed using RAOB. As can be seen from Figure 1, 2, and 4 of the atmospheric stability indices (especially for TT and KI) of Profiling Radiometer, there was a significant drop in the early of storm events. The reason is because the quality data from the Profiling Radiometer is not good enough at the time of the rainstorm. However, light rain does not significantly affect the quality of the data from the Profiling Radiometer as in the case of rain on January 30, 2016. Therefore, in this paper, the data is ignored.

Further, Figure 1-4 show that most of the instability indices from the Radiosonde data are always higher than the Profiling Radiometer data. The SWEAT index from the Profiling Radiometer was likely to stay below the Radiosonde data on Jan 29-31 and Feb 1-2 2016. The average of the highest deviation of SWEAT between Profiling Radiometer and those of Radiosonde is 100 points. A 100-point gap is considered significant and can alter atmospheric stability characteristics (see Table 1). Similarly, the K Index from Radiosonde has a higher value than the Profiling Radiometer during those observed days. The average maximum KI distinction between the Profiling Radiometer and the Radiosonde is 15 points. The difference can distinguish the convective characteristics which obtained from the Profiling Radiometer and the Radiosonde. However, in rain events, it seemed that the KI from the Profiling Radiometer almost reached the Radiosonde KI value. In addition, the Total-totals index from the Profiling Radiometer nearly reached the Radiosonde line during a storm event but still below those of the Radiosonde. It is also found that there are differences of 6 points between the TT index from the Profiling Radiometer and Radiosonde, which will influence the convective analysis.

However, data obtained from January 28, 2016, seems to be different from others. The Profiling Radiometer data increased significantly and exceeds the Radiosonde data in a storm event. It can be seen that the $\mathrm{K}$ index of the Profiling Radiometer started rising above the Radiosonde KI at 8 hours before the precipitation event with weak convective characteristics. According to Zahroh [3], Profiling Radiometer data with high-intensity rainfall can be predicted 6 hours before the storm event by noting the dramatic increase of instability indices. After that, the Profiling Radiometer KI increased beyond the Radiosonde KI with a 15-point gap at 10:30 UTC with moderate instability. However, after the storm event, the KI from Profiling Radiometer decreased below the KI of Radiosonde with 15 points gap. Besides, SWEAT index showed a similar pattern with KI. However, the SWEAT of Profiling Radiometer values started to be higher than the SWEAT of Radiosonde at 3 hours before a storm event. In contrast to KI and SWEAT, the Profiling Radiometer TT index began to exceed the Radiosonde TT index value at four hours before the precipitation event with weak convection. Then the TT index of Profiling Radiometer rose to exceed the Radiosonde data 2 hours before the storm event with a distinction of 2 points. After that, the TT Profiling Radiometer tended to decrease to a value below the Radiosonde TT with a difference of up to 5 points.

The radar indicated the presence of rain clouds when the instability indices were robust and also the number of rain rate. Figures 5-8 show radar images for Jakarta its surroundings. Each figure has five radar images: a) 2 UTC, b) 5 UTC, c) 8 UTC, d) 11 UTC, and e) 14 UTC. The black circles in the middle of the radar image show the location of Profiling Radiometer, and the radiosonde's launch point and the thick black boxes show radar image at the time of the storm. 


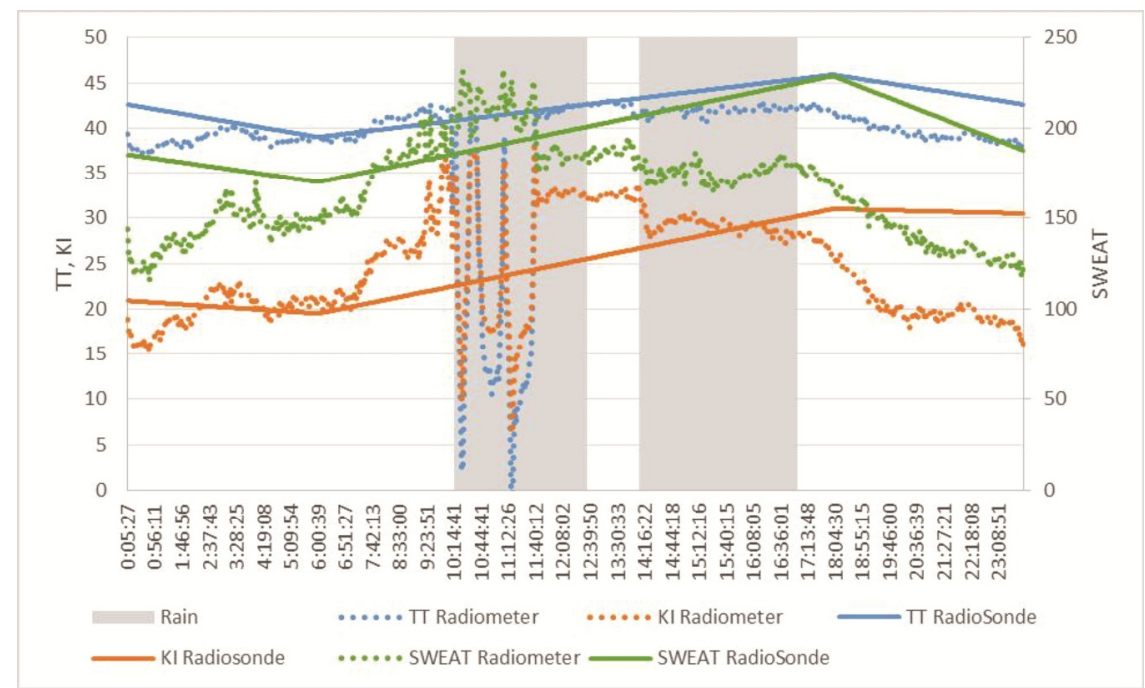

Fig. 1. Rain and TT Index, KI Index, SWEAT Index of Profiling Radiometer and Radiosonde Graph on January $28^{\text {th }}, 2016$.

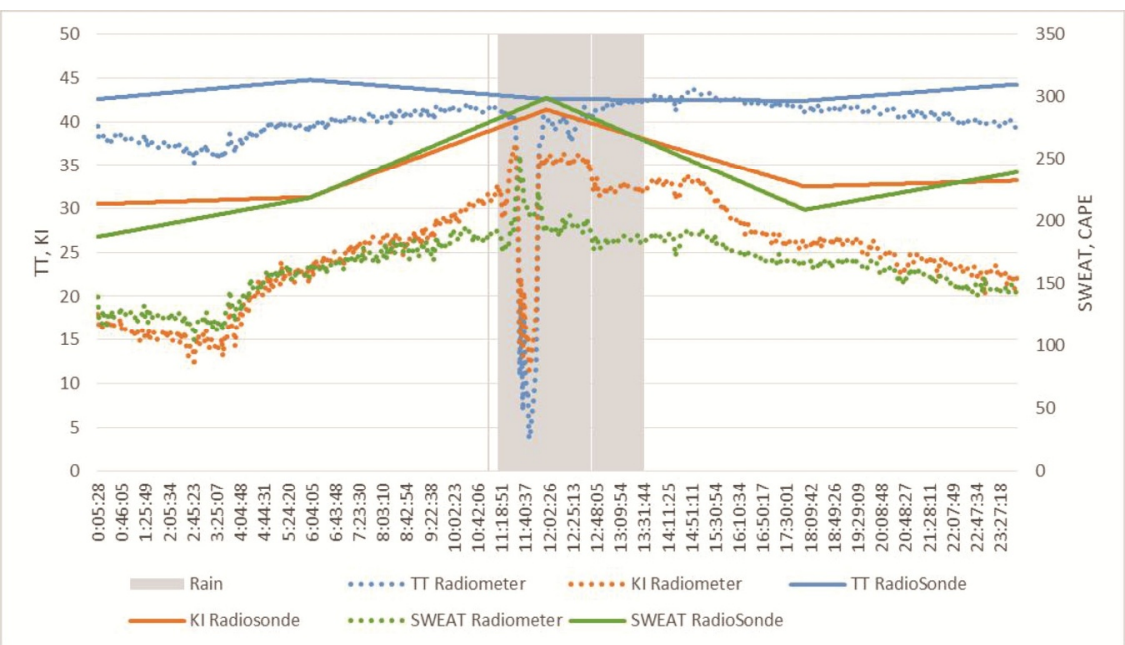

Fig. 2. Rain and TT Index, KI Index, SWEAT Index of Profiling Radiometer and Radiosonde Graph on January $29^{\text {th }}, 2016$.

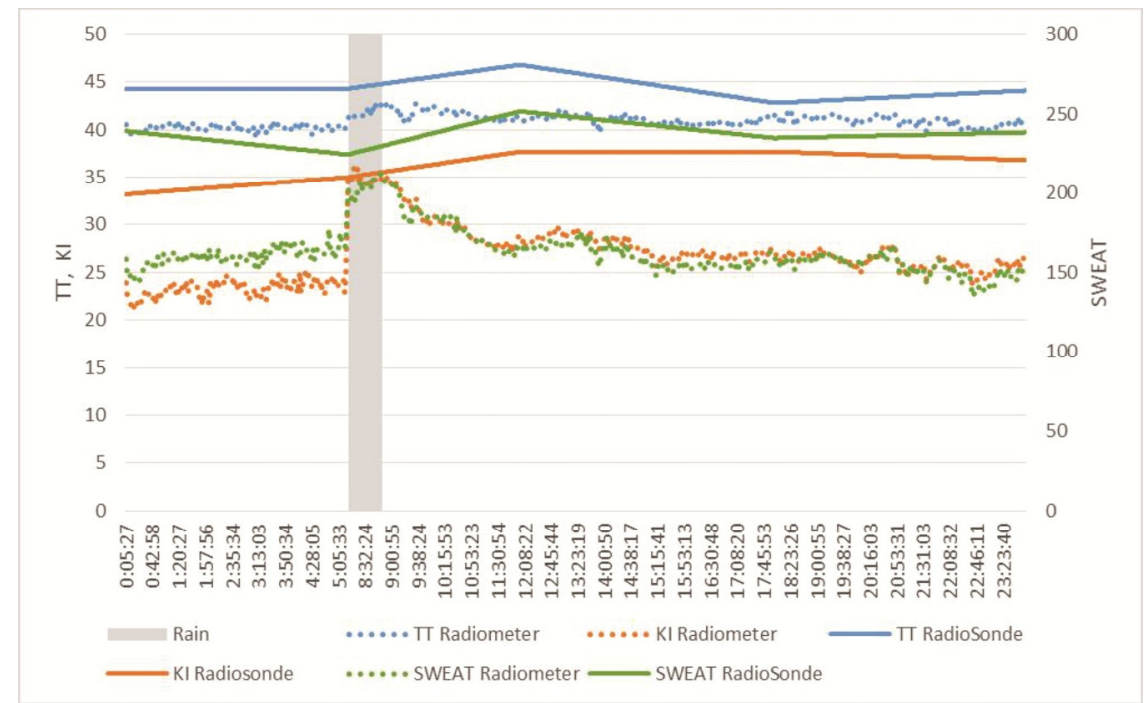

Fig. 3. Rain and TT Index, KI Index, SWEAT Index of Profiling Radiometer and Radiosonde Graph on January $30^{\text {th }}, 2016$. 


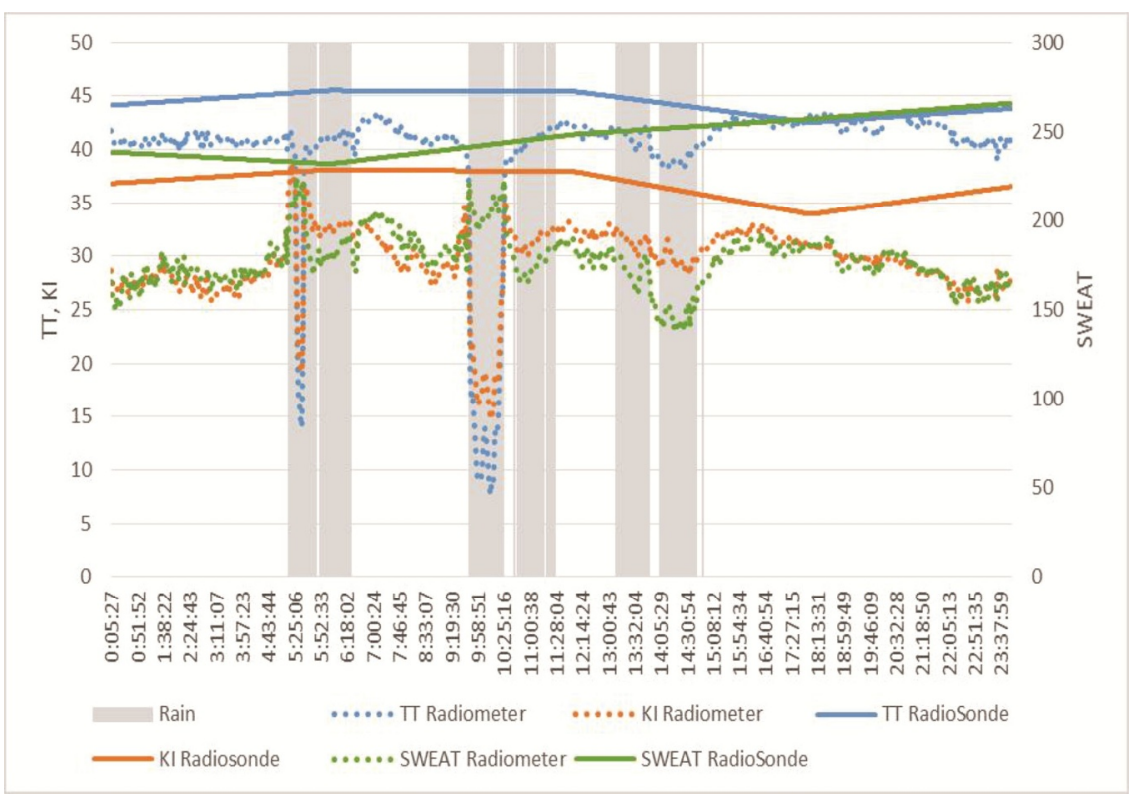

Fig. 4. Rain and TT Index, KI Index, SWEAT Index of Profiling Radiometer and Radiosonde Graph on January $31^{\text {st }}, 2016$.

There had been no cloud development on the radar at 2 and 5 UTC (Fig. 5). At 8 UTC, cloud began to appear in the east and southeast of the observation location. After that, the rain intensity was quite high at $11 \mathrm{UTC}$ with the rain rate reached more than $30 \mathrm{~mm}$ per hour. If we compare it with the Profiling Radiometer and Radiosonde data, the instability indices were strong convective. The rain began to subside with a rainfall rate of about $3 \mathrm{~mm} / \mathrm{h}$ at $14 \mathrm{UTC}$. The instability indices at that hour indicated a moderate level of storm. The rain rate of the radar shows similarities to the daily rainfall from the observation location that has $48 \mathrm{~mm}$ of rain (Table 2).

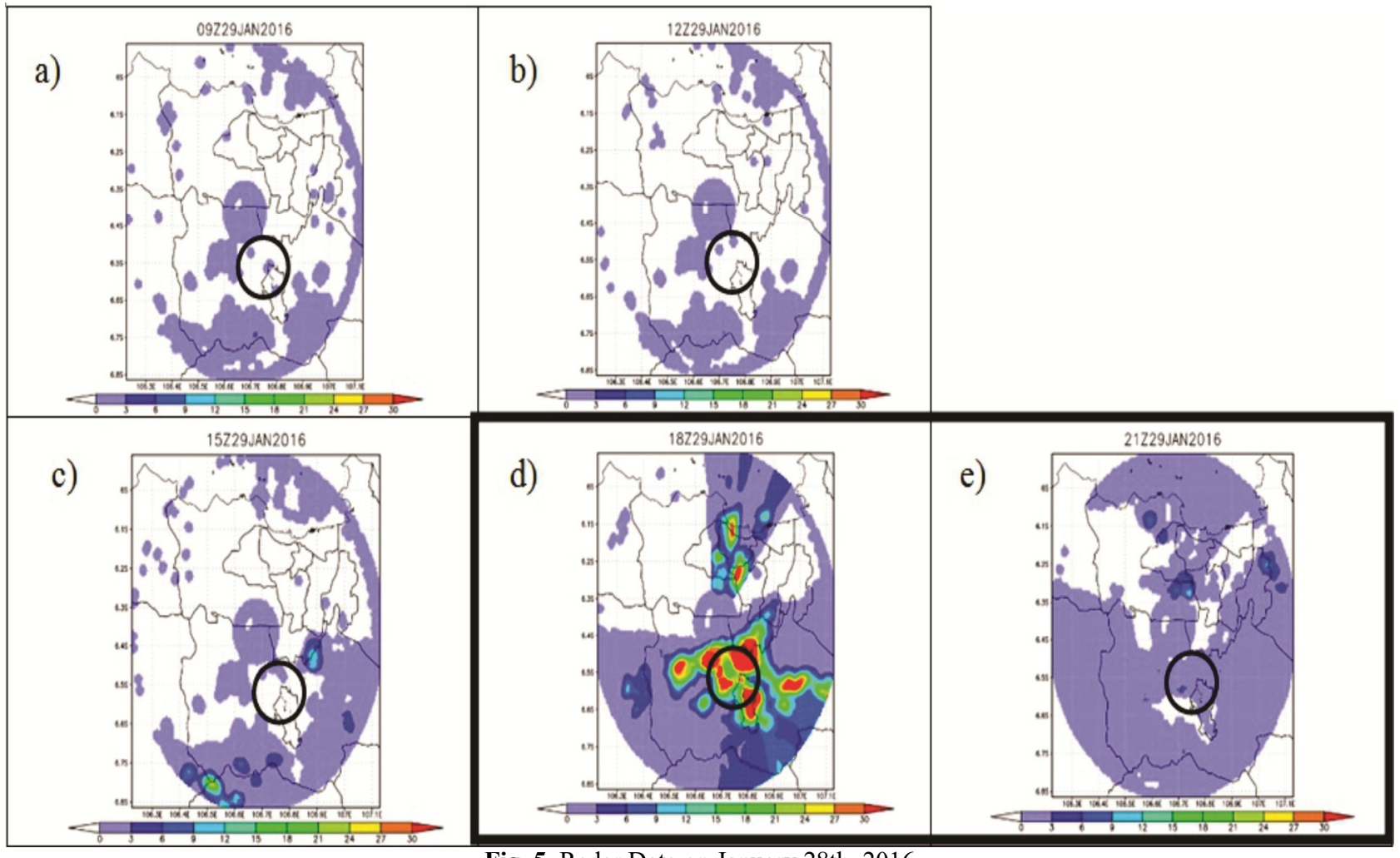

Fig. 5. Radar Data on January 28th, 2016 


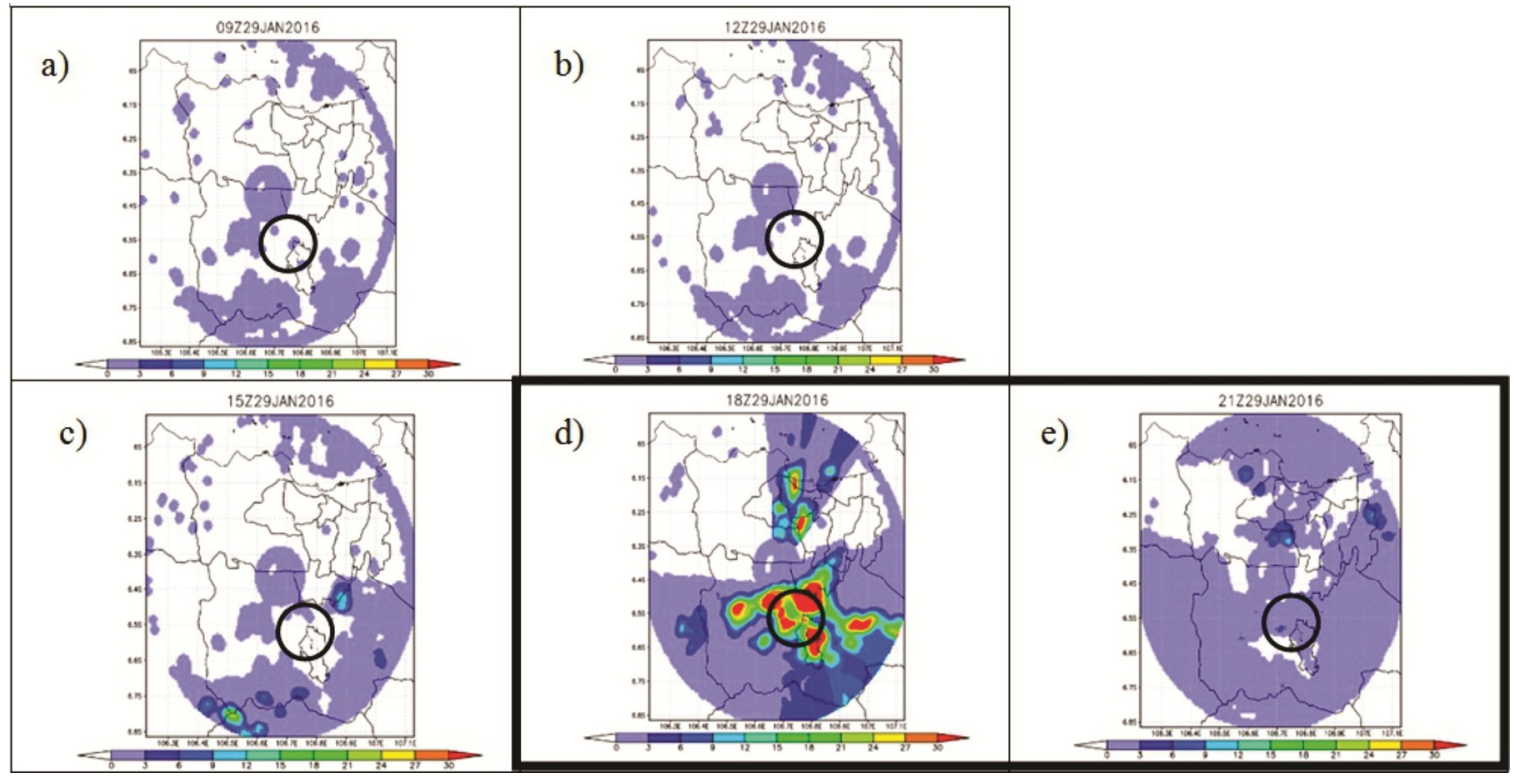

Fig. 6. Radar Data on January 29th, 2016

On January 29, 2016 (fig 6), the radar images are similar to radar images dated January 28, 2016, where the development of rain clouds began to appear at 8 UTC in the northeast and southwest of the observation site. After that, the rain cloud covered almost evenly distributed around the observation site with the rain rate reached more than $30 \mathrm{~mm}$ per hour at $11 \mathrm{UTC}$. In the radar image at $14 \mathrm{UTC}$, the rain began to subside with an intensity of $3 \mathrm{~mm}$ per hour. This radar image is the same with the KI and SWEAT of the Profiling Radiometer and Radiosonde indicating a strong storm at $11 \mathrm{am}$, and the rainstorm tends to moderate at 14 UTC.

Figure 7 shows that at 5 UTC there was rain cloud development in the northeast and southwest of the observation site. After that, there was light rain with intensity $3 \mathrm{~mm} /$ hour on radar image at 8 UTC. the data corresponds to Profiling Radiometer data that indicate rain event at 6-9 UTC with moderate storm category.

Three radar images on 31 January 2016 show the occurrence of rain in the observation area. From Profiling Radiometer's rain sensor we can see that the storm started from 5 UTC and the radar image shows up to $24 \mathrm{~mm}$ per hour of rain rate. However, the storm event at 9.30-11.30 UTC and 13-15 UTC can be seen from radar images at 11 UTC and 14 UTC that show rain rate about $3 \mathrm{~mm} /$ hour. Besides, the rain rate on that day has an association with the observed rainfall of $31 \mathrm{~mm}$ (see table 2).

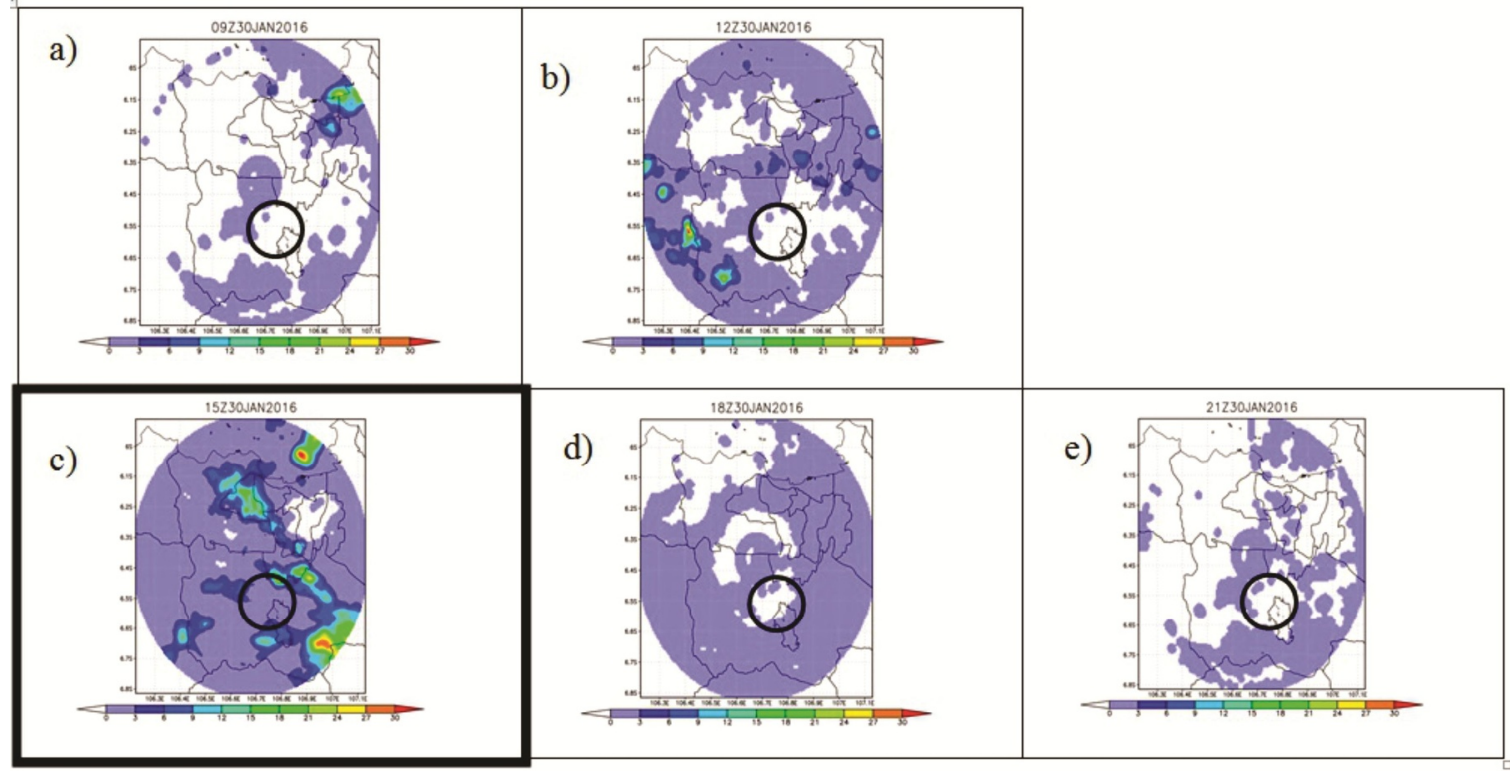

Fig. 7. Radar Data on January 30th, 2016 


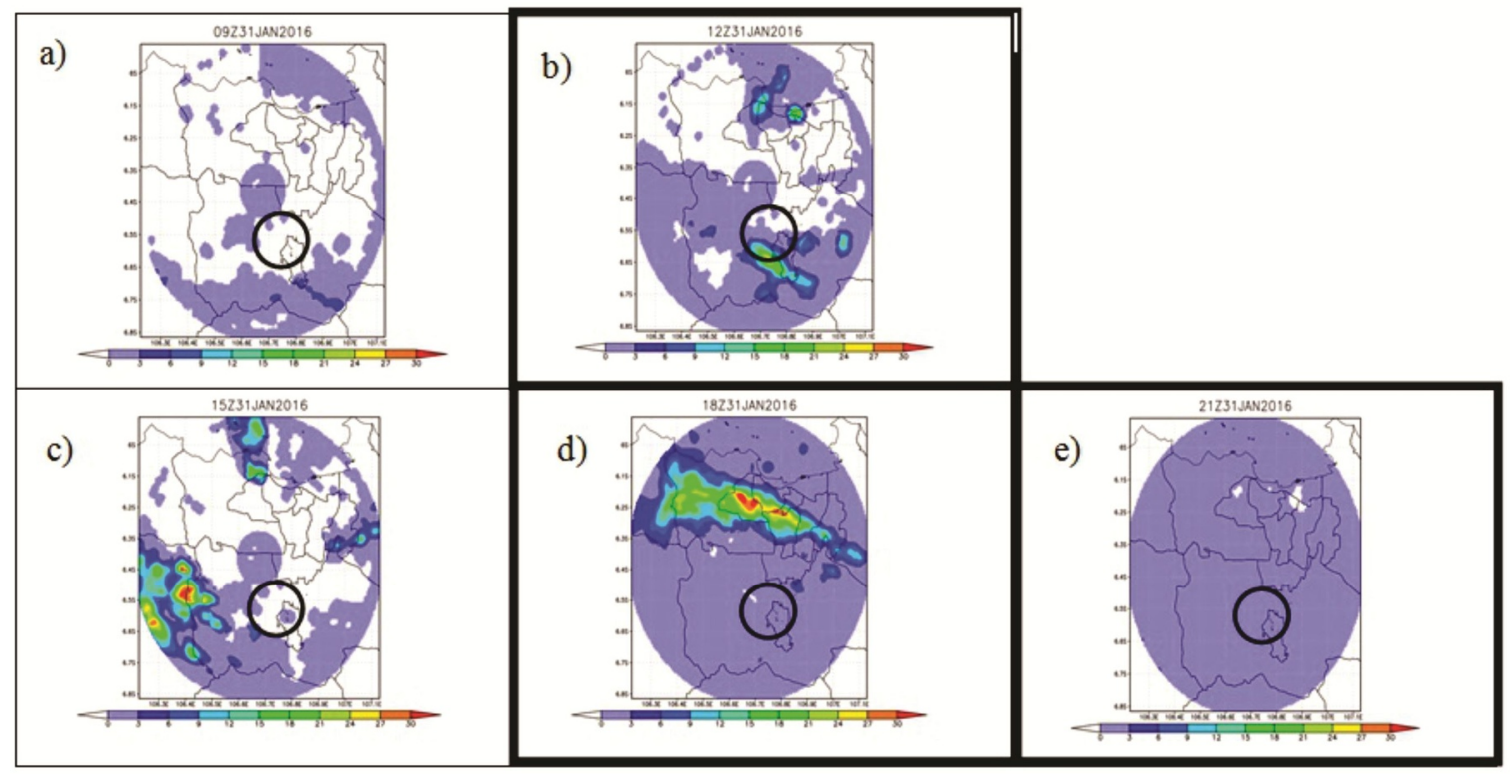

Fig. 8. Radar Data on January $31^{\text {st }}, 2016$.

\section{Conclusion}

The results showed that there were significant differences in instability indices of Radiosonde and Profiling Radiometer data: 15 points for KI, 6 points for TT, and 100 points for SWEAT. The atmospheric stability indices of the Profiling Radiometer tended to be lower than Radiosonde.

According to the indices interval of Budiarti [9], Radiosonde is better than a Radiometer on describing the characteristics of the extreme weather. This is because Radiosonde has strong convective during the storm whereas the Profiling Radiometer does not. However, Radiosonde cannot observe the parameter continuously as a Radiometer does. Nevertheless, both instruments produced a similar pattern of the indices where they increased in storm events and dropped when calm.

The rain rate on the radar indicated the presence of a storm at the observation site when the instability indices were robust. The number of rain rate is also correlated with the observed rainfall in BMKG, Dramaga. In other words, the rain rate data on the radar can represent the actual conditions of the observation site.

In conclusion, radar and atmospheric instability indices data integration can be used as one of the parameters to forecast extreme weather events and as an early warning system for hazard mitigation.

\section{References}

1. Athoillah, I., Dewi, S., Renggono, F. Comparison of Radiometer and Radiosonde Measurement in Rainy Season in Dramaga Bogor. J. Science \& Weather Modification Technology, Vol.17 No.2, 75 - 81 (2016)

2. Renggono, Findy. Observation of Weather Conditions for Flood Disasters: Cases of Flooding in
Cikampek Toll February 14, 2016. J. Science and Technology for Disaster Mitigation . vol. 1 (2017)

3. Zahroh, N.F., N.W.S.P. Dewi, dan D. Harsanti. Air Lability Index to Predict the Event of Thunder Storm in the Rainy Season Peak Period. J. Science and Weather Modification Technology, Vol.17 No.1, 25 - 33 (2017)

4. Doswell, Charles A. On Convective Indices and Sounding Classification. (Preprints, 5th Australian Severe Thunderstorm Conference, Bureau of Meteorology, 29 July - 2 August, 1996, Avoca Beach, New South Wales, Australia)

5. Kunz, M. The skill of convective parameters and indices to predict isolated and severe thunderstorms. Nat. Hazards Earth Syst. Sci., 7, 327-342 (2007)

6. Mayangwulan, D., Wiratmo, J., dan Siregar, P, M. Potential of Thunder Storm Events Based on Humidity Parameters, Air Lability, and Appointment Mechanism (Case Study: at Bandar Kadepara Biak). J. Aerospace Science. Vol. 8 No.2 : $139-156$ (2011)

7. Tajbakhsh, S., P. Ghafarian, F. Sahraian. Instability Indices and Forecasting Thunderstorms: The Case of 30 April 2009. Nat. Hazards Earth Syst. Sci., 12, 403 - 413 (2012)

8. Sibarani, Rini, A. Nugroho, and S. Wirahma. Dual Polarization Radar Parameter Analysis on Rainfall Events on February 14, 2016 in DKI Jakarta Region. J. Science \& Weather Modification Technology, Vol.17 No.1(2016)

9. Budiarti, M., M. Muslim, dan Y. Ilhamsyah. Study of Air Stability Index Against Thunder Storm Prediction in Cengkareng-Banten Meteorological Station Area. J. Meteorology and Geophysics. Vol. 13 No. 2 (2012)

10. Meilani., Wahid, A. Bernandus. Radiosonde Data Analysis to Know the Potential of Thunder Storm 
Events at El Tari Kupang Airport. (Proceedings of the 2014 Geophysics National Seminar)

11. Novianti, D, D., Anjani, U. Hernaeny. Thunder Storm Event Index Analysis at Cengkareng Meteorological Station with Rapid Miner and Fuzzy Logic Methods for Flight Safety. (2015 National Information and Multimedia Technology Seminar)

12. Ratnam, M. V.,Y. Durgha S., M. Rajeevan, S. Vijaya B. R. Diurnal Variability of Stability Indices Observed Using Radiosonde Observations Over a Tropical Station: Comparison with Microwave Radiometer Measurements. Atmospheric Research 124, 21 - 33 (2013)

13. Syaifullah, D. Atmospheric Potential in the Formation of Convective Clouds in the Implementation of Weather Modification Technology in Kotopanjang and Das Singkarak Watersheds 2010. Journal of Science \& Weather Modification Technology, Vol. 12, No. 1, 9-16 (2011) 